\title{
VITAMIN D STATUS IN NON-ALCOHOLIC FATTY LIVER DISEASE
}

\author{
By \\ Badran Ahmad Hamed, Youssef Khalil Ahmad, Esam Mohamed \\ Ghamry, Abd EL-Aziz Ahmad Aun* and Mohamed Abd El-Hamid \\ Basyoni Kidr**
}

Departments of Internal Medicine, Radiology* and Clinical Pathology**, Faculty of

Medicine, Al-Azhar University, Egypt

Mobile: 01289380442, E-mail: db.drbadr@gmail.com

\begin{abstract}
Background: Hypovitaminosis D has been recognized as a worldwide epidemic. Since vitamin D exerts significant metabolic activities comprising free fatty acids (FFA) flux regulation from the periphery to the liver, its deficiency may promote fat deposition into the hepatocytes.

Objective: To investigate plasma vitamin D levels in non-alcoholic fatty liver disease patients.

Patients and methods: This prospective study was carried out at Al-Hussein Hospital, Faculty of Medicine, Al- Azhar University, from June 2019 till December 2019. The present study included 40 middle aged patients which were divided into 2 equal groups: Patients with NAFLD, and patients with NASH who presented with elevated liver enzymes and newly diagnosed via abdominal Ultrasonography or computed tomography (CT). In addition, 20 apparently healthy subjects with normal weight and normal level of vitamin D were included as control group.

Results: There was a high significant positive correlation between serum vit. D3 and age, between serum vit D3 and serum albumin. There was a significant positive correlation between Serum VIT D3 and serum urea. Also, there was a high significant negative correlation between serum VIT D3 and ALT, AST, serum bilirubin, direct and 2hpp blood sugar, BMI and Hip circumference.
\end{abstract}

Conclusion: Lower serum 25(OH)D levels were found in NAFLD patients than in subjects without NAFLD.

Keywords: Vitamin D, Non-alcoholic Fatty Liver Disease, Hepatosteatosis, Prospective.

\section{INTRODUCTION}

Vitamin $\mathrm{D}$ has a significant role in many crucial physiological processes, including insulin resistance, muscle contraction, immune function, and calcium and bone metabolism. The prevalence of vitamin $\mathrm{D}$ deficiency ranges from 52 to $72 \%$ of the patients as indicated by several National Health Nutrition Surveys involving different countries (Szymczak-Pajor and Śliwińska, 2019).
The role of serum vitamin $\mathrm{D}$ was emphasized in chronic liver diseases and non-alcoholic fatty liver disease (NAFLD) in particular. For instance, a populationbased cohort study, consisting of 1081 participants, suggested that low serum vitamin D is closely related to NAFLD in patients with insulin resistance and diabetes, independent of abdominal visceral fat (Seo et al., 2013).

Another study compared 607 NAFLD patients with matched controls and found 
that low serum vitamin $\mathrm{D}$ concentrations were associated with NAFLD, and might have a role in the development and progression of NAFLD (Jablonski et al., 2013).

Dasarathy et al. (2013) evaluated 148 biopsy-proven NAFLD patients and found that serum vitamin $D$ was negatively correlated not only with hepatic steatosis and inflammation, but also with visceral and abdominal fat.

Furthermore, a case control study showed that NAFLD patients had low serum vitamin $\mathrm{D}$ due to inadequate vitamin D and calcium intake (Hashemi et al., 2013). Meta-analysis of 17 cross sectional studies also showed that serum 25-hydroxy vitamin D (25OHD) level had an association with fatty liver diseases (Eliades et al., 2013).

Moreover, a study assessing the amount of liver fat by proton magnetic resonance spectroscopy (1H-MRS) showed that plasma 25OHD levels were not associated with insulin resistance and intrahepatic fat accumulation. Although there are several studies clearly indicating decreased serum vitamin $D$ in patients with NAFLD, the mechanism is poorly understood (Seung et al., 2017).

Serum vitamin D is either synthesized by ultraviolet (UV) rays in the skin or taken orally. Vitamin D3 (cholecalciferol) in blood is transformed into 25-hydroxy vitamin $\mathrm{D}$ via the liver. It remains unclear whether the low vitamin D concentration associated with NAFLD is the result of decreased dietary intake, decreased sun exposure, or decreased conversion of $25(\mathrm{OH}) \mathrm{D}$ because of parenchymal liver disease. Since NAFLD is a consequence of nutritional over-intake, it remains highly controversial whether or not vitamin $\mathrm{D}$ intake is reduced in NAFLD patients (Han et al., 2014).

There is a lack of international research validating the routine screening of vitamin D deficiency and the effects of supplementation. Moreover, there is no evidence suggesting that NAFLD patients experience less sun exposure compared with non-NAFLD obese patients (Seung et al., 2017).

The present study aimed to investigate plasma vitamin D levels in NAFLD patients.

\section{PATIENTS AND METHODS}

The present study included 40 middle aged patients which were divided into 2 equal groups: Patients with NAFLD, and patients with NASH who presented with elevated liver enzymes and newly diagnosed via abdominal Ultrasonography or computed tomography (CT). In addition, 20 apparently healthy subjects with normal weight and normal level of vitamin D were included as control group. This prospective study was carried out at Al-Hussein Hospital, Faculty of Medicine, Al- Azhar University, from June 2019 till December 2019.

Exclusion criteria: Alcohol consumption, patients who took medications known to induce fatty liver, serum creatinine $>1.5$ $\mathrm{mg} / \mathrm{dl}$ or chronic renal disease, patients with hepatitis $\mathrm{B}$ or hepatitis $\mathrm{C}$, patients who received medication to control blood glucose, blood pressure, or lipid lowering agent, central obesity (waist circumference $>80 \mathrm{~cm}$ in women, $>90 \mathrm{~cm}$ in men), abnormal blood pressure (systolic $>130 \mathrm{mmHg}$ or diastolic > $85 \mathrm{mmHg}$ ), abnormal triglycerides (>150 mg/dl), low 
HDL cholesterol $(<50 \mathrm{mg} / \mathrm{dl})$ and abnormal fasting glucose $(>100 \mathrm{mg} / \mathrm{dl})$.

Clinical assessment: Complete history taking, clinical examination: BMI and waist and hip circumference and anthropometric measurements.

Laboratory assessment (routine and general evaluation tests):

Complete blood count, liver function tests (serum bilirubin "total, direct and indirect", ALT, AST, total proteins and serum albumin), serum levels of 25Hydroxy vitamin D $\mathrm{ng} / \mathrm{ml}$ : Serum is separated and stored in $-25^{\circ} \mathrm{C}$ for few days. 25(OH) vitamin $\mathrm{D}$ levels were measured using The Alegria ${ }^{\circledR}$ 25-OH Vitamin D3/D2 Test Strip (ORGENTEC Diagnostika GmbH Carl-Zeiss-Straße 4951 Mainz - Germany). It is an ELISA based test.

Radiological assessment: Abdominal ultrasonography (US), Abdominal
Contrast-enhanced computed tomography (CT) scan in HCC patients.

\section{Statistical analysis:}

Analysis of data was done using Statistical Package for the Social Sciences version 20 (SPSS Inc., Chicago, IL, USA). Quantitative variables were described in the form of range, mean and standard deviation. Quantitative variables were described in the form of mean and standard deviation. Qualitative variables were described as number and percent. In order to compare parametric quantitative variables between two groups, Student's ttest was performed. Qualitative variables were compared using chi-square (X2) test or Fisher's exact test when frequencies were below five. Pearson correlation coefficients were used to assess the association between two normally distributed variables. When a variable was not normally distributed. A P value $<0.05$ was considered significant.

\section{RESULTS}

There were significant differences between the studied groups as regard age, ALT, AST, serum bilirubin direct, serum bilirubin total, serum albumin, serum urea, serum create, F.B. sugar, 2hpp, serum cholesterol, serum T.G, HDL, LDL, serum VIT D3, SBP, DBP, BMI, waist 
circumference and hip circumference (Table 1).

Table (1): Comparison between the three groups regarding the studied parameters

\begin{tabular}{|c|c|c|c|c|c|c|c|c|c|c|c|c|c|c|}
\hline \multirow{2}{*}{\multicolumn{2}{|c|}{ Parameters }} & \multirow{2}{*}{\multicolumn{3}{|c|}{$\begin{array}{c}\text { Patients with } \\
\text { NAFLD } \\
\text { N=20 }\end{array}$}} & \multirow{2}{*}{\multicolumn{3}{|c|}{\begin{tabular}{|c|} 
Patients with \\
NASH \\
$\mathbf{N}=\mathbf{2 0}$ \\
\end{tabular}}} & \multirow{2}{*}{\multicolumn{3}{|c|}{$\begin{array}{c}\text { Control } \\
\mathbf{N}=\mathbf{2 0}\end{array}$}} & \multirow{4}{*}{$\begin{array}{c}\text { ANOVA } \\
\text { P-value } \\
<0.001\end{array}$} & \multicolumn{3}{|c|}{ TUKEY'S Test } \\
\hline & & & & & & & & & & & & I\&II & I\&III & II\&III \\
\hline \multirow{2}{*}{ Age (Years) } & Range & 39 & & 44 & 35 & & 40 & 34 & & 40 & & & & \\
\hline & Mean \pm SD & 41.55 & \pm & 1.395 & 38.5 & & 1.318 & 37.7 & & $=1.593$ & & $<0.00$ & $<0.001$ & 0.193 \\
\hline \multirow{2}{*}{ ALT (U/L) } & & 48 & & 60 & 70 & & 90 & 25 & & 38 & \multirow{2}{*}{$<0.001$} & \multirow{2}{*}{$<0.001$} & \multirow{2}{*}{$<0.001$} & \multirow{2}{*}{$<0.001$} \\
\hline & ean \pm SD & 53.3 & \pm & 3.114 & 80.35 & & \begin{tabular}{|l|}
5.641 \\
\end{tabular} & 29.85 & \pm & 4.133 & & & & \\
\hline \multirow{2}{*}{ AST (U/L) } & & 50 & & 70 & 75 & & 95 & 20 & & 37 & \multirow{2}{*}{$<0.001$} & \multirow{2}{*}{$<0.001$} & \multirow{2}{*}{$<0.001$} & \multirow{2}{*}{$<0.001$} \\
\hline & Mean \pm SD & 56 & \pm & 5.758 & 84.85 & & 6.002 & 32.25 & \pm & $=4.598$ & & & & \\
\hline \multirow{2}{*}{$\begin{array}{l}\text { Serum Bilirubin } \\
\text { Direct (mg/dl) }\end{array}$} & & 0.25 & & 0.39 & 0.37 & & 0.44 & 0.2 & & 0.27 & \multirow{2}{*}{$<0.001$} & \multirow{2}{*}{$<0.001$} & \multirow{2}{*}{$<0.001$} & \\
\hline & $\pm \mathrm{SD}$ & 0.32 & \pm & 0.04 & 0.397 & & 0.019 & 0.229 & \pm & 0.028 & & & & \\
\hline Serum Bilirubin & & 1 & & 1.3 & 1.1 & & 1.5 & 0.8 & & 1.1 & & & & \\
\hline & \pm SD & 1.17 & \pm & 0.108 & 1.26 & & 0.119 & 0.975 & \pm & $=0.079$ & & & & \\
\hline & & 3.5 & - & & 3 & & 4.1 & 3.9 & & 5 & & & & \\
\hline & Meal & 3.965 & \pm & 0.272 & 3.695 & & 0.265 & 4.62 & & $=0.375$ & & & & \\
\hline & & 20 & - & 37 & 20 & & 28 & 15 & & 25 & & & & \\
\hline & Mea & 29 & & 5.292 & 23.4 & + & 2.604 & 20.9 & \pm & $=2.594$ & & & & \\
\hline & & 0.8 & & \begin{tabular}{|l|}
1.1 \\
\end{tabular} & 0.8 & & \begin{tabular}{|l|}
1.1 \\
\end{tabular} & 0.6 & & 0.9 & & 0114 & & 0001 \\
\hline & Mear & 0.923 & + & 0.09 & 0.98 & & 0.101 & \begin{tabular}{|l|}
0.823 \\
\end{tabular} & \pm & $=0.073$ & & & & \\
\hline & & 90 & & & 85 & & & \begin{tabular}{|l|}
85 \\
\end{tabular} & & 100 & & 0.004 & & 0.001 \\
\hline & SSD & 101.95 & \pm & 5.042 & 96.3 & & 6.586 & \begin{tabular}{|l|}
89.85 \\
\end{tabular} & & $=4.158$ & & & & \\
\hline & & 100 & & 120 & 105 & & 135 & \begin{tabular}{|l|}
80 \\
\end{tabular} & & 110 & & & & \\
\hline & Mea & 110.75 & \pm & 6.742 & 120.2 & \pm & 7.824 & 97.65 & & $=8.171$ & & & & \\
\hline & & 110 & & 150 & 170 & & 185 & 95 & & 130 & & & & \\
\hline & \pm SD & 132 & \pm & 11.286 & 163.6 & & 36.574 & 114.25 & \pm & $=9.072$ & & & & \\
\hline & & 125 & & 145 & 129 & & 148 & \begin{tabular}{|l|}
89 \\
\end{tabular} & & 110 & & & & \\
\hline & \pm SD & 135.85 & \pm & 6.268 & 139.85 & \pm & 5.184 & 99.1 & \pm & 6.215 & & & & \\
\hline & & 40 & & 60 & 45 & & 65 & 40 & & 55 & & 002 & 034 & 001 \\
\hline & SSD & 51.75 & \pm & 5.684 & 58 & & 5.712 & 47.25 & I & 5.22 & & & 0.034 & $<0.001$ \\
\hline & & 70 & & 90 & 80 & & 98 & 50 & & 68 & & & & \\
\hline & SD & 80.45 & \pm & 5.083 & 89.25 & & 5.035 & 60.15 & $I$ & 5.153 & & & & \\
\hline & & 11 & & 17 & 8 & & 13 & 35 & & 50 & & & & \\
\hline & Mea & 14.65 & \pm & 1.565 & 10.8 & & 1.361 & 42.3 & \pm & 5.212 & & & & \\
\hline & & 100 & & 115 & 105 & & 125 & 95 & & 110 & & & & \\
\hline & \pm SD & 108.25 & \pm & 4.94 & 116 & & 7.182 & 100.25 & \pm & $=5.495$ & & & & \\
\hline & & 60 & & 75 & 60 & & 85 & 60 & & 80 & & & & \\
\hline & \pm SD & 68 & I & 4.974 & 72.75 & & 7.34 & 69 & \pm & 5.282 & & & & \\
\hline & & 19 & 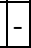 & 22 & 20 & & 24 & 17 & & 22 & & & & \\
\hline & \pm SD & 20.6 & \pm & 1.142 & 22.4 & & 1.095 & 19.6 & \pm & 1.536 & & & & \\
\hline Waist circumfer & & 70 & $C_{3}$ & 80 & 72 & & 81 & 67 & & 77 & & 20 & & 6000 \\
\hline & Mean \pm SD & 73.85 & \pm & 2.925 & 76.1 & & 2.469 & 71.15 & & 2.758 & & & & \\
\hline Hip circumference & & 87 & & 94 & 90 & & 98 & 80 & & 88 & & & & \\
\hline (2ii) & Mean \pm SD & 90.65 & \pm & 1.954 & 94.45 & \pm & 2.139 & 84.65 & \pm & 2.084 & -0.001 & $<0.001$ & $<0.001$ & $<0.001$ \\
\hline
\end{tabular}

There were high significant positive correlations between Serum VIT D3 and age and between Serum VIT D3 serum albumin, there is significant positive correlation between Serum VIT D3 and serum urea, also there is high significant negative correlation between Serum VIT D3 and ALT, AST, Serum Bilirubin Direct, 2hpp, BMI and Hip circumference, there is significant negative correlation between Serum VIT D3 and Serum Bilirubin Total, Serum Cholesterol, HDL, 
LDL, SBP, DBP and Hip circumference, but there is no significant correlation between Serum VIT D3 and F.B. Sugar or Serum T.G (Table 2).

Table (2): Correlation between Vit $D$ and other studied parameters

\begin{tabular}{|c|c|c|c|c|c|c|}
\hline Groups & \multicolumn{2}{|c|}{ Patients with NAFLD } & \multicolumn{2}{l|}{ Patients with NASH } & \multicolumn{2}{c|}{ Total } \\
\cline { 2 - 7 } Parameters & r & P-value & r & P-value & r & P-value \\
\hline Age (Years) & 0.069 & 0.773 & 0.000 & 1.000 & 0.621 & $<0.001$ \\
\hline ALT (U/L) & -0.129 & 0.589 & -0.175 & 0.459 & -0.790 & $<0.001$ \\
\hline AST (U/L) & -0.397 & 0.083 & 0.028 & 0.906 & -0.789 & $<0.001$ \\
\hline Serum Bilirubin Direct (mg/dl) & -0.163 & 0.492 & -0.229 & 0.332 & -0.694 & $<0.001$ \\
\hline Serum Bilirubin Total (mg/dl) & 0.059 & 0.805 & -0.085 & 0.723 & -0.308 & 0.043 \\
\hline Serum Albumin (g/dl) & 0.353 & 0.127 & 0.070 & 0.769 & 0.486 & 0.001 \\
\hline Serum Urea (mg) & -0.222 & 0.346 & -0.214 & 0.365 & 0.351 & 0.026 \\
\hline Serum Create (mg/dl) & -0.379 & 0.099 & -0.146 & 0.539 & -0.385 & 0.014 \\
\hline F.B. Sugar (mg/dl) & -0.196 & 0.408 & -0.263 & 0.263 & 0.234 & 0.145 \\
\hline 2hpp (mg/dl) & -0.273 & 0.244 & -0.213 & 0.366 & -0.564 & $<0.001$ \\
\hline Serum Cholesterol (mg/dl) & -0.405 & 0.076 & 0.432 & 0.057 & -0.320 & 0.044 \\
\hline Serum T.G (mg/dl) & -0.016 & 0.945 & -0.154 & 0.518 & -0.311 & 0.051 \\
\hline HDL (mg/dl) & -0.075 & 0.752 & 0.047 & 0.843 & -0.403 & 0.010 \\
\hline LDL (mg/dl) & 0.100 & 0.674 & 0.200 & 0.399 & -0.470 & 0.002 \\
\hline SBP & 0.257 & 0.274 & -0.194 & 0.413 & -0.433 & 0.005 \\
\hline DBP & 0.243 & 0.301 & -0.522 & 0.018 & -0.391 & 0.013 \\
\hline BMI & -0.230 & 0.330 & -0.120 & 0.614 & -0.593 & $<0.001$ \\
\hline Waist circumference (cm) & -0.449 & 0.047 & 0.147 & 0.536 & -0.423 & 0.007 \\
\hline Hip circumference (cm) & 0.078 & 0.743 & 0.014 & 0.952 & -0.533 & $<0.001$ \\
\hline
\end{tabular}

\section{DISCUSSION}

The exact mechanism of NAFLD development is unknown. However, NAFLD has the potentiality of progression to nonalcoholic steatohepatitis (NASH), cirrhosis and hepatocellular carcinoma (HCC). It is commonly associated with insulin resistance and metabolic syndrome (Younossi et al., 2018).

Vitamin D has many functions in many systems of the human body including muscles, bone, heart, gut, liver and immune system (Vernetti et al., 2017). Vitamin D may have a role in development of autoimmune diseases and inflammatory conditions through production of inflammatory cytokines (Alhassan et al., 2017).
Some studies found a significant association between vitamin D deficiency and obesity, metabolic syndrome, type 2 diabetes and insulin resistance (Zaki et al., 2017). Nonalcoholic fatty liver disease (NAFLD) is the most common hepatic disease in adolescents and its prevalence has risen substantially in recent decades (Cho et al., 2019).

Several different parallel processes participate in the development of NAFLD (Adams et al., 2017) and many potential risk factors for NAFLD, including obesity, insulin resistance, and metabolic syndrome, have been identified. Vitamin $\mathrm{D}$ deficiency has been investigated as a risk factor for the development of NAFLD and several studies have suggested that vitamin D levels were inversely associated with NAFLD in adults (Cimini et al., 
2019). However, few studies have investigated the relationship between vitamin D deficiency and NAFLD in an adolescent population (Cho et al., 2019).

Vitamin D status has traditionally been considered an important factor in calciumassociated metabolism. In addition, recent attention has focused on the extra-skeletal effects of vitamin D (Cho et al., 2019) and increasing evidence has shown that low serum vitamin D levels were associated with obesity and metabolic syndrome (Mahmood et al., 2017).

Shawky et al. (2018) conducted a cross sectional study in Egypt performed to investigate the association between NAFLD and serum $25(\mathrm{OH})$ vitamin D, they enrolled 50 patients with NAFLD cases.

In the present study, serum levels of Vit D. were significantly lower in patients than controls and in NASH patients than patients with NEFLD. This was in agreement with Shawky et al. (2018) who reported that Serum $25(\mathrm{OH})$ vitamin D levels were significantly reduced in patients with NAFLD than those without NAFLD (18.76 vs $40.36 \mathrm{p}$ value 0.000). Serum $25(\mathrm{OH})$ vitamin D levels decreased with the increase in the NAFLD grade. However, no significant difference in serum $25(\mathrm{OH})$ vitamin $\mathrm{D}$ level between patients with grade 1 NAFLD and those without NAFLD, but there were significant differences between patients with grade 2 and 3 on one hand and those with grade 1 and 0 on the other hand.

In the present study, serum levels of ALT, AST, Serum Bilirubin Direct, Serum total Bilirubin, Serum Albumin, Serum urea, Serum create, Serum FBS, 2hpp, Serum Cholesterol, Serum TG,
Serum HDL and Serum LDL were significantly higher in patients than controls and in NASH patients than those with NEFLD. Shawky et al. (2018) verified that patients with NAFLD showed higher white blood cell count, fasting blood sugar (FBS), ALT, triglycerides and total cholesterol levels than controls. Also, Cho et al. (2019) noticed in their study that glucose, cholesterol, and TG levels were higher in adolescents with suspected NAFLD than in adolescents without suspected NAFLD.

Küçükazman et al. (2014) found that NAFLD and control groups did not differ in terms of gender or age. Also, they illustrated that the NAFLD group had significantly higher fasting blood glucose (FBG), uric acid, aspartate aminotransferase (AST), alanine aminotransferase (ALT), cglutamyltransferase (GGT), alkaline phosphatase (ALP), HbA1c, ferritin, insulin, C-peptide, HOMA-IR, total cholesterol, triglyceride (TG) and white blood cell (WBC) levels. In contrast, the NAFLD group had significantly lower 25OHD levels compared with those of the control group.

Fogelstrand and Boren (2012) investigated the role of $25(\mathrm{OH}) \mathrm{D}$ in NAFLD patients and matched the NAFLD group with a presumably healthy population that did not undergo liver US. They found a strong inverse relationship between NAFLD and 25(OH)D levels. Also, Barchetta et al. (2011) found strong association between hypovitaminosis D and NAFLD which was independent on age, sex, BMI, lipid profile or glucose level. 
Rhee et al. (2013) found a minor but significant difference in $25(\mathrm{OH}) \mathrm{D}$ levels between patients with and without NAFLD. However, Park et al. (2017) showed that vitamin D deficiency was significantly related to NAFLD in men but not in women. Cho et al. (2019) stated that adolescents with suspected NAFLD had significantly lower 25(OH)D levels than adolescents without suspected NAFLD.

Chung et al. (2016), Nelson et al. (2016) and Zhai et al. (2016) found that low levels of vitamin D are associated with high risk of NASH in patients with NAFLD and vitamin D deficient patients have 1.26-fold increased risk for NAFLD than those with sufficient vitamin D.

In contrast to our results, Liangpunsakul and Chalasani (2011) conducted adult population-based studies in which they have noted that low vitamin D levels were independently related to NAFLD. Also, our results were in contrary with Patel et al. (2016) and De Paula et al. (2017) who found no significant differences between patients with NAFLD and those without NAFLD in serum vitamin D levels.

In another study by Katz et al. (2011), low vitamin D levels were not found to be an independent predictor of suspected NAFLD in 1,630 adolescents after adjusting for obesity. These contradictory results among studies may be related to differences in the studied population, nutritional and environmental factors. Nobili et al. (2014) showed that low vitamin D levels were independently associated with liver biopsy-proven NAFLD in adolescents.
Nair (2010) stated that the mechanisms by which $25(\mathrm{OH})$ vitamin $\mathrm{D}$ may induce NAFLD is not clear. The liver converts vitamin $\mathrm{D}$ to its active form, $25(\mathrm{OH})$ vitamin $\mathrm{D}$, so in liver diseases the 25 $(\mathrm{OH})$ vitamin D level. Eliades and Spyrou (2015) found that vitamin D deficiency may induce NAFLD by impairing hepatic lipid metabolism.

Alvarez and Ashraf (2010) demonstrated that Patients with vitamin D deficiency found to have high rates of insulin resistance, metabolic syndrome and inflammatory mediators including IL4, IL-6 and TNF- $\alpha$. Barchetta et al. (2012) reported that vitamin $\mathrm{D}$ receptors widely exist in liver tissue with negative association between vitamin $\mathrm{D}$ receptors expression and necro-inflammatory grades of NASH. However, Earthman et al. (2012) stated that Vitamin D may be sequestrated in the adipose tissue in obese patients.

In the present work, we found that there was a significant positive correlation between Serum VIT D3 and age and between Serum VIT D3 serum albumin. There was a significant positive correlation between Serum VIT D3 and serum urea. Also, there were significant negative correlations between Serum VIT D3 and ALT, AST, Serum Bilirubin Direct, 2hpp, BMI and Hip circumference. There were significant negative correlations between Serum VIT D3 and Serum Bilirubin Total, Serum Cholesterol, HDL, LDL, SBP, DBP and Hip circumference, but there were no significant correlations between serum vit D3 and FBS or Serum T.G.

This was in concordant with Shawky et al. (2018) who showed that serum $25(\mathrm{OH})$ 


\section{BADRAN A. HAMED et al.,}

vitamin D levels were found to be correlated with age, BMI, ALT, AST, triglycerides, LDL and total cholesterol. Küçükazman et al. (2014) stated that the levels of $25(\mathrm{OH}) \mathrm{D}$ were significantly correlated with BMI, HbA1c levels, the urinary albumin/creatinine ratio, FBG levels, the erythrocyte sedimentation rate (ESR), uric acid levels, total cholesterol levels, LDL-C levels and HDL-C levels.

\section{CONCLUSION}

Serum 25OHD levels were lower in NAFLD patients than in subjects without NAFLD. This finding may have been related to low UV light exposure in the winter months or to genetic differences between different cultures.

\section{REFERENCES}

1. Adams LA, Anstee QM, Tilg $H$ and Targher G (2017): Non-alcoholic fatty liver disease and its relationship with cardiovascular disease and other extrahepatic diseases. Gut, 66(6): 1138-1153.

2. Alhassan MH, Mirshafiey A, Vahedi $H$, Hemmasi G, Parastoui $K$ and Saboor A (2017): Immunoregulation of inflammatory and inhibitory cytokines by vitamin D 3 in patients with inflammatory bowel diseases. Scandinavian journal of immunology, 85(6): 386-394.

3. Alvarez, J. A. and Ashraf, A. (2010): Role of vitamin $\mathrm{D}$ in insulin secretion and insulin sensitivity for glucose homeostasis. International journal of endocrinology, 2: 351-385.

4. Barchetta I, Carotti S, Labbadia G, Gentilucci UV, Muda AO, Angelico F and Morini S. (2012): Liver vitamin D receptor, CYP2R1, and CYP27A1 expression: relationship with liver histology and vitamin D3 levels in patients with nonalcoholic steatohepatitis or hepatitis C virus. Hepatology, 56(6): 2180-2187.
5. Barchetta, I., Angelico, F., Del Ben, M., Baroni, M. G., Pozzilli, P., Morini, S. and Cavallo, M. G. (2011): Strong association between non alcoholic fatty liver disease (NAFLD) and low $25(\mathrm{OH})$ vitamin D levels in an adult population with normal serum liver enzymes. BMC Medicine, 9(1): 85-98.

6. Cho, Y. H., Kim, J. W., Shim, J. O., Yang, H. R., Chang, J. Y., Moon, J. S. and Ko, J. S. (2019): Association between vitamin D deficiency and suspected nonalcoholic fatty liver disease in an adolescent population. Pediatric Gastroenterology, Hepatology \& Nutrition, 22(3): 233-241.

7. Chung, G. E., Kim, D., Kwak, M. S., Yang, J. I., Yim, J. Y., Lim, S. H. and Itani, M. (2016): The serum vitamin $D$ level is inversely correlated with nonalcoholic fatty liver disease. Clin. Mol. Hepatol., 22 (1): 146-151.

8. Cimini, F. A., Barchetta, I., Carotti, S., Morini, S. and Cavallo, M. G. (2019): Overview of studies of the vitamin D/vitamin $D$ receptor system in the development of nonalcoholic fatty liver disease. World Journal of Gastrointestinal Pathophysiology, 10(2): 1115.

9. Dasarathy, J., Periyalwar, P. and Allampati, S (2013): Hypovitaminosis D is associated with increased whole body fat mass and greater severity of non-alcoholic fatty liver disease [published online ahead of print 5, Liver Int.; 34(6):e118-27.

10. De Paula, F. V. L., Ramalho, L. N. Z., De Paula, F. J. A. and Martinelli, A. D. L. C. (2017): Low vitamin D level is not associated with severity of non-alcoholic fatty liver disease in morbidly obese patients. Journal of Hepatology, 66(1): S157-S161.

11. Earthman, C. P., Beckman, L. M., Masodkar, K. and Sibley, S. D. (2012): The link between obesity and low circulating 25 hydroxyvitamin D concentrations: considerations and implications. International Journal of Obesity, 36(3): 387-396.

12. Eliades, M. and Spyrou, E. (2015): Vitamin D: a new player in non-alcoholic fatty liver disease?. World Journal of Gastroenterology: WJG; 21(6):1718-1729. 
13. Eliades, M., Spyrou, E., Agrawal, N., Lazo, M., Brancati, F. L., Potter, J. J. and Hernaez, R. (2013): Meta-analysis: vitamin $\mathrm{D}$ and non-alcoholic fatty liver disease. Alimentary Pharmacology \& Therapeutics, 38(3): 246-254.

14. Fogelstrand, P. and Boren, J. (2012): Retention of atherogenic lipoproteins in the artery wall and its role in atherogenesis. Nutrition, Metabolism and Cardiovascular Diseases, 22(1): 1-7.

15. Han, S.S., Kim, M.H., Lee, S.M., Lee, J.P., Kim, S.J., Joo, K.W., Lim, C.S., Kim, Y.S.and Kim, D.K. (2014): Association between body fat and vitamin $\mathrm{D}$ status in Korean adults. Asia Pacific journal of clinical nutrition; 23(1):65-75.

16. Hashemi, M., Bojd, H.H., Nasab, E.E., Bahari, A., Hashemzehi, N.A., Shafieipour, S., Narouie, B., Taheri, M. and Ghavami, S. (2013): Association of adiponectin rs1501299 and rs266729 gene polymorphisms with nonalcoholic fatty liver disease. Hepatitis Monthly; 13(5).

17. Jablonski, K.L., Jovanovich, A., Holmen, J., Targher, G., McFann, K., Kendrick, J. and Chonchol, M. (2013): Low 25hydroxyvitamin D level is independently associated with non-alcoholic fatty liver disease. Nutrition, Metabolism and Cardiovascular Diseases; 23(8):792-8.

18. Katz, K., Brar, P. C., Parekh, N., Liu, Y. H. and Weitzman, M. (2011): Suspected nonalcoholic Fatty liver disease is not associated with vitamin $d$ status in adolescents after adjustment for obesity. Journal of Obesity; 2: 456-468.

19. Küçükazman, M., Ata, N., Dal, K., Yeniova, A. Ö., Kefeli, A., Basyigit, S. and Nazligül, Y. (2014): The association of vitamin $\mathrm{D}$ deficiency with non-alcoholic fatty liver disease. Clinics, 69(8): 542-546.

20. Liangpunsakul, S. and Chalasani, $\mathbf{N}$. (2011): Serum vitamin D concentrations and unexplained elevation in ALT among US adults. Digestive Diseases and Sciences, 56(7): 2124-2135.
21. Mahmood, L. A., Al Saadi, R. and Matthews, L. (2017): Vitamin D deficiency and cardiometabolic syndrome: Is the evidence solid?. Archives of Medicine and Health Sciences, 5(2): 229-239.

22. Nair, S. (2010): Vitamin d deficiency and liver disease. Gastroenterology \& Hepatology; 6(8):491-503.

23. Nelson, J. E., Roth, C. L., Wilson, L., Yates, K., Aouizerat, B., MorganStevenson, V. and Yeh, M. M. (2016): Vitamin D Deficiency is Associated with Increased Risk of Nonalcoholic Steatohepatitis in Adults with Nonalcoholic Fatty Liver Disease: possible role for MAPK and NF-kB?. The American Journal of Gastroenterology, 111(6): 852-868.

24. Nobili, V., Giorgio, V., Liccardo, D., Bedogni, G., Morino, G., Alisi, A. and Cianfarani, S. (2014): Vitamin D levels and liver histological alterations in children with nonalcoholic fatty liver disease. Eur J Endocrinol., 170(4): 547-53.

25. Park, D., Kwon, H., Oh, S. W., Joh, H. K., Hwang, S. S., Park, J. H. and Park, J. H. (2017): Is vitamin $D$ an independent risk factor of nonalcoholic fatty liver disease?: a cross-sectional study of the healthy population. Journal of Korean Medical Science, 32(1): 95-101.

26. Patel, Y. A., Henao, R., Moylan, C. A., Guy, C. D., Piercy, D. L., Diehl, A. M. and Abdelmalek, M. F. (2016): Vitamin D is not associated with severity in NAFLD: results of a paired clinical and gene expression profile analysis. The American Journal of Gastroenterology, 111(11): 1591-1612.

27. Rhee, E. J., Kim, M. K., Park, S. E., Park, C. Y., Baek, K. H., Lee, W. Y. and Oh, K. W. (2013): High serum vitamin D levels reduce the risk for nonalcoholic fatty liver disease in healthy men independent of metabolic syndrome. Endocrine Journal, EJ12-387.

28. Seo, J.A., Eun, C.R., Cho, H., Lee, S.K., Yoo, H.J., Kim, S.G., Choi, K.M., Baik, S.H., Choi, D.S., Yim, H.J., and Shin, C. (2013): Low vitamin D status is associated with nonalcoholic Fatty liver disease 


\section{BADRAN A. HAMED et al.,}

independent of visceral obesity in Korean adults. PLoS One; 8(10): e75197.

29. Seung, S.J., Ha, E.K., Jee, H.M., Lee, K.S., Lee, S.W., Kim, M., Kim, D.H., Jung, Y.H., Sheen, Y.H., Sung, M.S., and Han, M.Y. (2017): Prevalence and risk factors of urticaria with a focus on chronic urticaria in children. Allergy, Asthma \& Immunology Research; 9(3):212-9.

30. Shawky, M. A. E. G., Hassan, A. M., Mohammed, A. Q. and Orabi, M. I. (2018): Vitamin D levels in Egyptian patients with non-alcoholic fatty liver disease. Journal of Gastroenterology and Hepatology Research, 7(1): 2530-2534.

31. Szymczak-Pajor, I. and Śliwińska, A. (2019): Analysis of association between vitamin D deficiency and insulin resistance. Nutrients, 11(4):794-802.

32. Vernetti, L., Gough, A., Baetz, N., Blutt, S., Broughman, J. R., Brown, J. A. and Kovbasnjuk, O. (2017): Functional coupling of human microphysiology systems: intestine, liver, kidney proximal tubule, blood-brain barrier and skeletal muscle. Scientific Reports, 7: 422-426.
33. Younossi, Z., Anstee, Q. M., Marietti, M., Hardy, T., Henry, L., Eslam, M. and Bugianesi, E. (2018): Global burden of NAFLD and NASH: trends, predictions, risk factors and prevention. Nature Reviews Gastroenterology \& Hepatology, 15(1): 1120.

34. Zaki, M., Kamal, S., Basha, W. A., Youness, E., Ezzat, W., El-Bassyouni, H. and Amr, K. (2017): Association of vitamin $\mathrm{D}$ receptor gene polymorphism (VDR) with vitamin $\mathrm{D}$ deficiency, metabolic and inflammatory markers in Egyptian obese women. Genes \& Diseases, 4(3): 176-182.

35. Zhai, H. L., Wang, N. J., Han, B., Li, Q., Chen, Y., Zhu, C. F. and Lu, M. (2016): Low vitamin D levels and non-alcoholic fatty liver disease, evidence for their independent association in men in East China: a crosssectional study (Survey on Prevalence in East China for Metabolic Diseases and Risk Factors (SPECT-China)): British Journal of Nutrition, 115(8): 1352-1359. 


\section{حالة فيتامين (د) فى مرض الكبد الدهني غير الكحولي} بلران أحمد حامد، يوسف خليل أحمد، عصام محمد غمري، عبد العزيز أحمد عون*، محمد عبد الحميا بسيوني خضر **

أقسام الامراض الباطنية وألاشعة* والباثولوجيا الإكلينيكية**، كلية الطب، جامعة الأزهر، مصر

E-mail: $\underline{\text { db.drbadr@gmail.com }}$

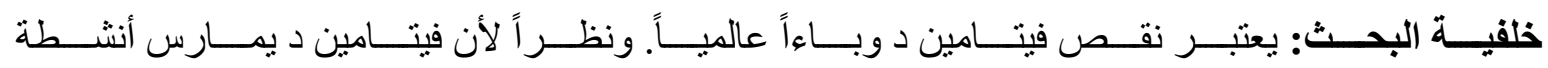

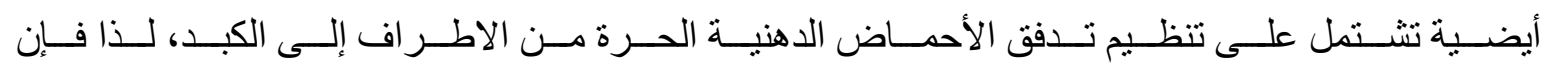
نقص فيتامين د قد يعزز ترسب الدهون في خلايا الكبد.

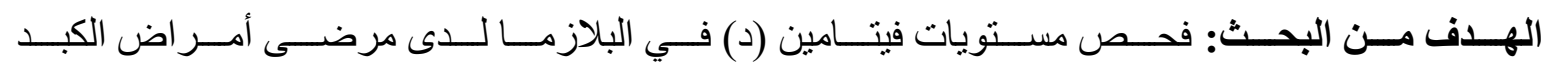
الدهني غير الكحولي.

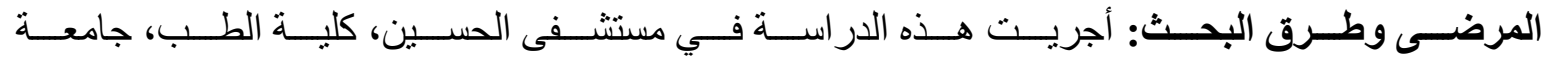

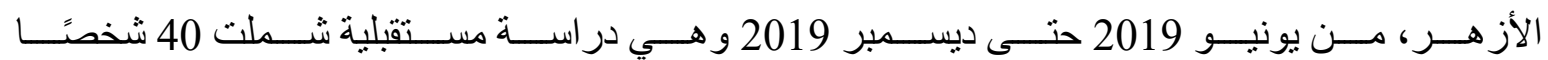

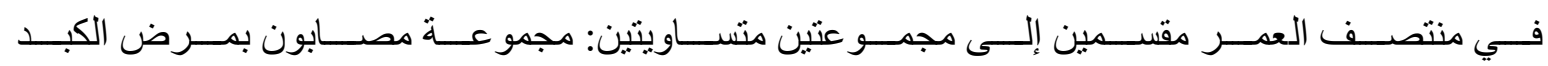

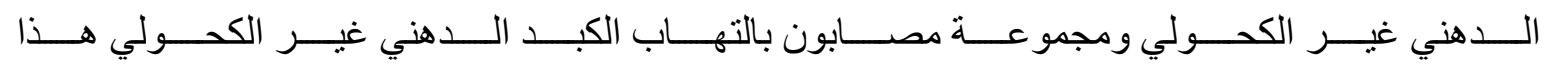

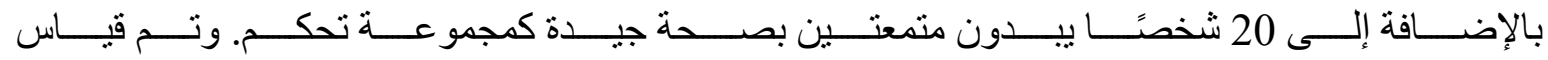

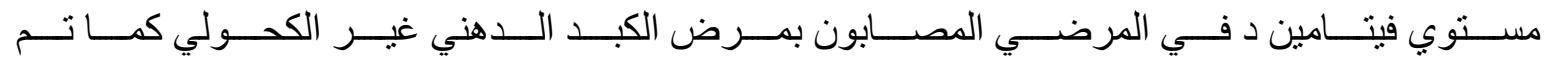
قياس فيتامين د في مجمو عة التحكم.

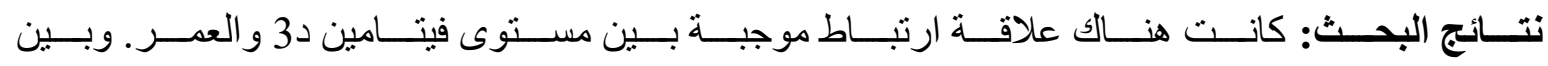

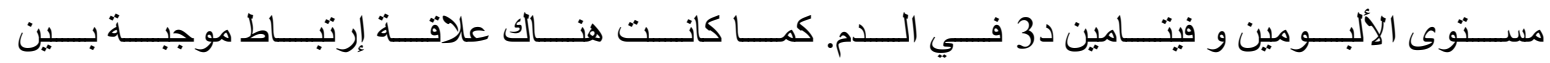

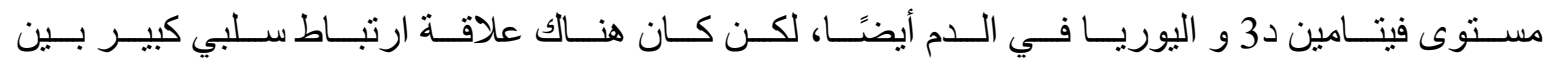

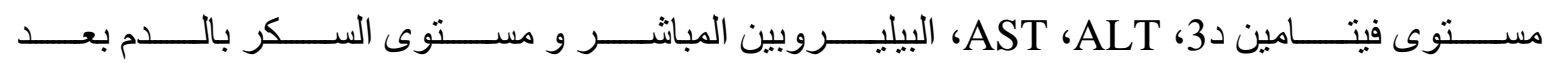
الوجبة بساعتين، مؤشر كتلة الجسم ومحيط الورك.

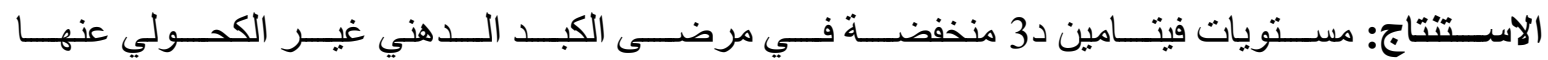
في الأشخاص الغير مصابين بمرض الكبد الدهني غير الكحولي.

الكلمات الدالة: فيتامين د، مرض الكبد الدهني غير الكحولي، تنكس الكبد، إستباقية. 